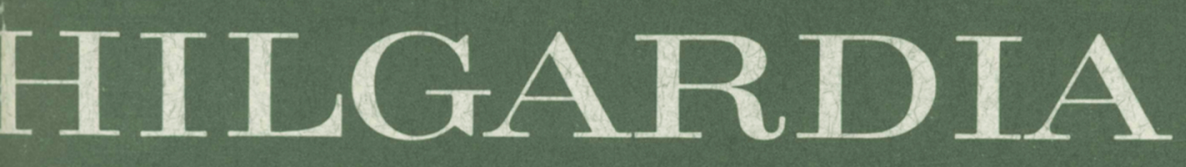

JOURNAL OF AGRICULTURAL SCIENCE PUBLISHED BY HE CALIFORNIA AGRICULTURAL EXPERIMENTSTATION

Volume 35, Number $21 \cdot$ October, 1964

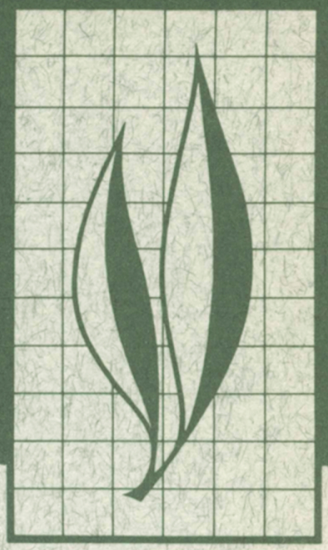

\title{
Pythiaceous Fungi
}

\section{and Plant-Parasitic Nematodes}

\section{in California Pear Orchards}

I. Occurrence and Pathogenicity of

Pythiaceous Fungi in

\section{Orchard Soils}

Carl W. Nichols, S. M. Garnsey, R. L. Rackham,

S. M. Gotan, and C. N. Mahannah

II. Incidence and Distribution of Parasitic Nematodes in Orchard Soils

Alex M. French, B. F. Lownsbery, S. M. Ayoub, A. C. Weiner, and N. El-Gholl

III. Effect of Reduction of Nematode Populations by Soil Fumigation on Subsequent Growth of Pear Seedlings

B. F. Lownsbery, J. T. Mitchell, and S. M. Paracer 


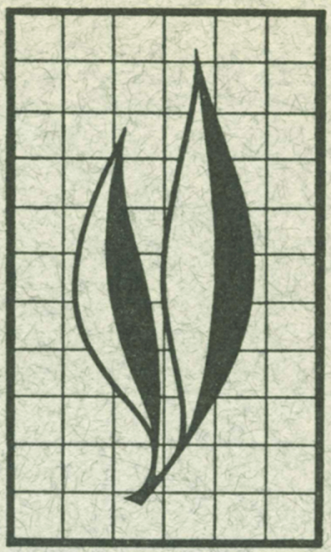

Pythiaceous Fungi and Plant-Parasitic Nematodes in California Pear Orchards

I. During a year's survey of 126 California pear orchards with varying degrees of pear-decline damage, a total of 3,586 isolates of soil-borne fungi of the genera Pbytophthora and Pythium were recovered, and, where possible, identified as to species.

A direct relationship was found between the severity of pear-decline damage in an orchard and the percentage of isolates from the orchard that were Pythium spp.; and a corresponding inverse relationship between peardecline damage severity and the percentage of isolates that were Phytophthora spp.

Isolates of Phytophthora cactorum and $P$. cryptogea were found to be pathogenic on Pyrus communis L. hort. var. Winter Nelis and Pyrus serotina Rehd. seedlings. These pathogens were found infrequently, and it was concluded that pythiaceous fungi were not the primary cause of pear decline.

\section{THE AUTHORS}

I. Carl W. Nichols is Plant Pathologist and Program Supervisor of Special Projects, Bureau of Plant Pathology, California Department of Agriculture, Sacramento. S. M. Garnsey was formerly Research Assistant, Department of Plant Pathology, Davis, and is now Plant Pathologist at the Horticultural Field Station, U.S. Department of Agriculture, Orlando, Florida; R. L. Rackham was formerly Extension Technologist in the Agricultural Extension Service, Davis, and is now a University of California Farm Advisor in the Agricultural Extension Service, San Bernardino County; S. M. Gotan is Plant Pathologist, Bureau of Plant Pathology, California Department of Agriculture, Sacramento; C. N. Mahannah is Research Assistant, Department of Irrigation, Davis.

II. Alex M. French is Program Supervisor of Plant Nematology, Bureau of Plant Pathology, California Department of Agriculture, Sacramento. S. M. Ayoub and A. C. Weiner are Plant Nematologists, Bureau of Plant Pathology, California Department of Agriculture, Sacramento. N. El-Gholl is now Plant Pathologist, Riverside County Department of Agriculture, Riverside.

III. B. F. Lownsbery is Associate Nematologist, in the Experiment Station, Davis. J. T. Mitchell is Laboratory Technician and S. M. Paracer is a graduate student in the Department of Nematology, Davis. 


\section{Effect of Reduction of Nematode Populations by Soil Fumigation on Subsequent Growth of Pear Seedlings ${ }^{1}$}

\section{INTRODUCTION}

Pears ARE NOT very susceptible to disease induced by root-knot nematodes, Meloidogyne spp. (Day and Tufts, 1944; Tyler, 1944), or the root-lesion nematode Pratylenchus vulnus Sher and Allen (Day and Serr, 1951). However, a survey of California pear orchards (French et al., pp. 603-610, this issue) showed that other kinds of plant-parasitic nematodes are commonly associated with pears in this state. The pin nematode Paratylenchus hamatus Thorne and Allen, and spiral nematodes, Helicotylenchus spp., are frequently present in high population densities. The effect of these nematodes on pears has never been studied. The experiment reported here is a first step in determining this effect.

\section{METHODS}

Soil from pear root zones in each of six heavily nematode-infested (table 1) pear orchards was thoroughly mixed, and divided into two 10-gal. portions, which were put into 10 -gal. cans. The soil in one of these cans was treated with ethylene dibromide (Dowfume W-85; 83 per cent 1,2-dibromoethane by wt.) at the rate of $1.5 \mathrm{ml}$ per can (approx. 16 gal. per acre). A polyethylene cover was taped over the can to retain the fumigant. Ethylene dibromide was chosen because Aldrich and Martin (1952) reported it to have fewer chemical and microbiological effects, other than the nematicidal one, than some soil fumigants. The chosen dosage was one which we had previously found to be effective in reducing nematode populations when applied under the conditions established here. A fumigation period of one week was used, after which the treated soil was aerated for another week. During this two-week period the untreated soil was stored in a cool place. Then, in May, 1962, Pyrus communis var. Bartlett and $P$. serotina ( $P$. pyrifolia, an Oriental pear) seedlings about $8 \mathrm{~cm}$ tall were transplanted into 6 -inch clay plots of the fumigated and the untreated soils. Pear seedlings planted in untreated soil were paired on lathhouse benches with the same kind of seedlings growing in fumigated soils from the same source. There were 10 replicates of each soil source, soil treatment, and pear-seedling combination. Soil temperature was uncontrolled except for the use in summer of a plastic screen

\footnotetext{
${ }^{1}$ Submitted for publication April 3, 1964.
} 
over the lath, combined with an intermittent mist on hotter days to keep summer maximums in the $80-90^{\circ} \mathrm{F}$ range.

Five replicates were harvested after five months. The remaining five replicates were harvested after one year. Fresh weights for entire plants, with roots washed free of soil and blotted dry, were used as the criterion of growth. Weights of plants grown in treated and in untreated soil were compared, using Student's $T$ test (Paterson, 1939).

Nematode population levels in the soil were determined at planting time and at harvest times, with the use of a mist-extraction procedure (Lownsbery and Serr, 1963).

TABLE 1

POPULATION LEVELS* OF THE PRINCIPAL PLANT-PARASITIC NEMATODES

IN THE SIX PEAR-ORCHARD SOILS UNDER STUDY BEFORE AND AFTER ONE YEAR'S GROWTH OF PEAR SEEDLINGS

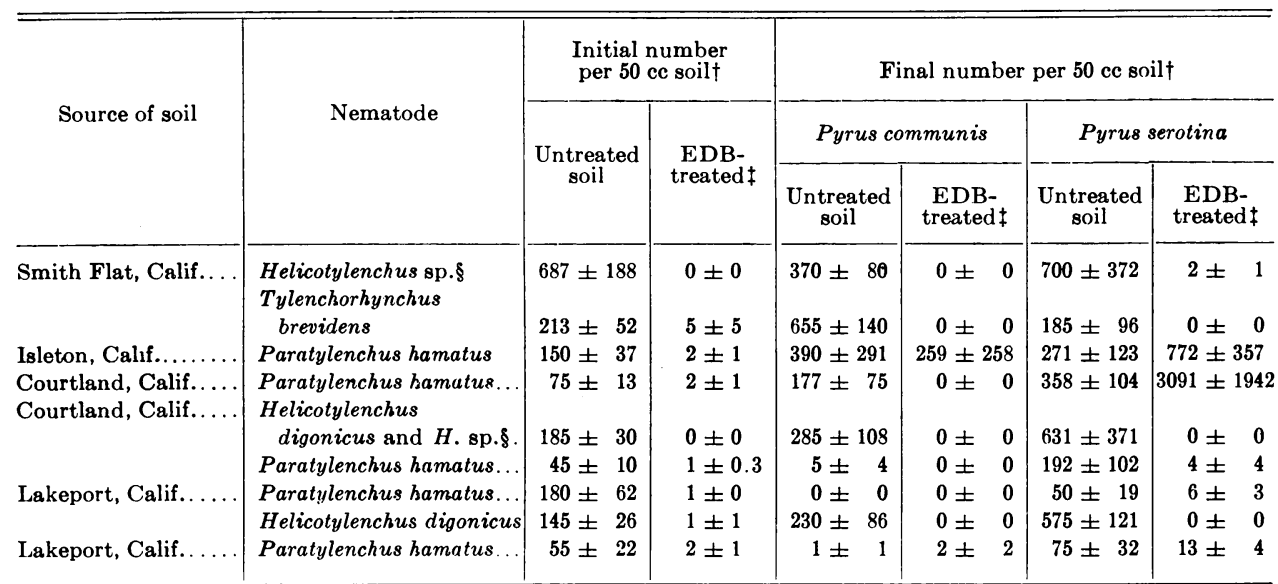

* Mean of 5 replicates and standard error of this mean.

$\dagger$ Recovered by one week's incubation under a heated intermittent mist.

$\$$ "Dowfume W $85 "-16 \mathrm{~g} / \mathrm{A}$.
$\S$ An undescribed species of Helicotylenchus.

\section{RESULTS AND CONCLUSIONS}

Paratylenchus hamatus Thorne and Allen, Helicotylenchus digonicus Perry, an undescribed species of Helicotylenchus, and Tylenchorhynchus brevidens Allen were present in these orchard soils. Fumigation with ethylene dibromide reduced the numbers of these nematodes in the treated soil (table 1 ). This reduction was maintained for the duration of the experiment for nine of the 12 comparisons (table 1 ).

Final weights of pear seedlings after one year's growth are given in table 2 . Similar results were obtained for the replicates harvested after five months' growth. There were no highly significant differences between weights of seedlings grown in fumigated and nonfumigated soils. One of the 12 differences was significant at the 5 per cent level.

We saw no qualitative differences (e.g., in leaf color, or root form) between pear seedlings grown in treated and in untreated soils. Because the principal effect of soil treatment was reduction in nematode population, we conclude that the nematodes present in these soils (table 1) did not limit the growth of Pyrus communis var. Bartlett, or $P$. serotina seedlings.

It is possible that Paratylenchus hamatus or Helicotylenchus spp. may limit pear growth under conditions 
other than those which we provided. Xiphinema americanum Cobb, a virus vector (Fulton, 1962) which occurs in nearly all pear orchards, may be of importance. The present evidence, how- ever, indicates that pears are less afflicted by nematode disease in California than are many other deciduous fruits (Lownsbery, Serr, and Hansen, 1959).

TABle 2

WEIGHTS OF PEAR SEEDLINGS* AFTER ONE YEAR'S GROWTH IN ETHYLENE DIBROMIDE-TREATED $\dagger$ AND IN UNTREATED PEAR-ORCHARD SOILS

\begin{tabular}{|c|c|c|c|c|c|c|}
\hline \multirow[t]{2}{*}{ Source of soil } & \multicolumn{2}{|c|}{ Soil treatment } & \multirow{2}{*}{$\begin{array}{l}\text { LSD at the } \\
1 \% \text { level }\end{array}$} & \multicolumn{2}{|c|}{ Soil treatment } & \multirow{2}{*}{$\begin{array}{c}\text { LSD at the } \\
1 \% \text { level }\end{array}$} \\
\hline & EDB-treated & Untreated & & EDB-treated & Untreated & \\
\hline Smith Flat, Calif... & $\begin{array}{c}g m \\
41 \pm 10\end{array}$ & $\begin{array}{c}g m \\
28 \pm 6\end{array}$ & 39 & $\begin{array}{c}g m \\
52 \pm 1\end{array}$ & $\begin{array}{c}g m \\
61 \pm 4\end{array}$ & 15 \\
\hline Courtland, Calif... & $40 \pm 4$ & $28 \pm 7$ & 30 & $49 \pm 5$ & $47 \pm 6$ & 26 \\
\hline Courtland, Calif.......... & $36 \pm 5$ & $29 \pm 5$ & 24 & $39 \pm 16$ & $52 \pm 4$ & 55 \\
\hline Lakeport, Calif.... & $20 \pm 7$ & $24 \pm 5$ & 29 & $50 \pm 11$ & $70 \pm 8$ & 46 \\
\hline Lakeport, Calif... & $34 \pm 5 t$ & $15 \pm 4$ & 21 & $54 \pm 4$ & $43 \pm 7$ & 27 \\
\hline
\end{tabular}

* Mean of 5 replicates and standard error of the mean.

$\dagger$ "Dowfume W 85" - $16 \mathrm{~g} / \mathrm{A}$.

$\ddagger$ Significantly higher than the untreated at the $5 \%$ level $(\mathrm{LSD}=15)$

\section{SUMMARY}

When plant-parasitic nematode populations in pear orchard soils were reduced by fumigation with ethylene dibromide, the treatment resulted in no increase in growth of Pyrus communis var. Bartlett or $P$. serotina (Oriental pear) seedlings. The principal nematodes present in these soils were the pin nematode Paratylenchus hamatus
Thorne and Allen, the spiral nematode Helicotylenchus digonicus Perry, an undescribed species of Helicotylenchus, and the stunt nematode Tylenchorhynchus brevidens Allen. Therefore, no evidence was obtained to indicate a correlation between population density of these nematodes and pear vigor. 


\section{LITERATURE CITED}

Aldrich, D. G., and J. P. MARTin

1952. Effect of fumigation on some chemical properties of soils. Soil Science 73:149-59.

DAY, L. H., and E. F. SERR

1951. Comparative resistance of rootstocks of fruit and nut trees to attack by a root lesion or meadow nematode. Proc. Amer. Soc. Hort. Sci. $57: 150-54$.

DAy, L. H., and WARREN P. TuFTS

1944. Nematode-resistant rootstocks for deciduous fruit trees. Calif. Agr. Expt. Sta. Cir. 359. $16 \mathrm{pp}$.

French, A. M., B. F. Lownsbery, S. M. Ayoub, A. C. Weiner, and N. El-Gholl

1964. Pythiaceous fungi and plant-parasitic nematodes in California pear orehards. II: Incidence and distribution of parasitic nematodes in orchard soils. Hilgardia $35(21): 603-10$.

Fulton, Joseph P.

1962. Transmission of tobacco ringspot virus by Xiphinema americanum. Phytopathology $52: 375$.

LownSBERY, B. F., and E. F. SERR

1963. Fruit and nut rootstocks as hosts for a root-lesion nematode, Pratylenchus vulnus. Proc. Amer. Soc. Hort. Sci. $82: 250-54$.

Lownsbery, B. F., E. F. SERr, and C. J. HANSEN

1959. Deciduous fruit and nut trees. Root-knot nematode on peach and root-lesion nematode on walnut cause serious problems for California orchardists. Calif. Agr. 13(9):19-20.

Paterson, D. D.

1939. Statistical technique in agricultural research. McGraw-Hill Book Co., Inc., New York, N.Y. 263 pp.

TYLER, JOCELYN

1944. The root-knot nematode. Calif. Agr. Expt. Sta. Cir. 330 (Rev.). 30 pp.

In our publications it is sometimes convenient to use trade names of products or equipment rather than scientific identifications. In so doing it is unavoidable in some cases that similar products which are on the market under other trade names may not be cited. No endorsement of named products is intended, nor is any criticism implied of similar products which are not mentioned. 
Pear fruit and pear and apple seedlings trapped more Pythium spp. than the fruit of apple, lemon, and avocado, while few Pbytophthora spp. were trapped in seedlings. Phytophtbora spp. isolates were trapped most often in pear and apple fruit. Lemon and avocado fruit yielded a fair number of both genera.

II. Plant-parasitic nematodes of various types are prevalent in the upper root zone of pear trees in California. Monthly samplings over a 12-month period, from the same 126 orchards mentioned above, showed that the dagger nematode Xiphinema americanum and the pin nematode Paratylenchus bamatus occurred in more than 90 per cent of the orchards and in all pear-growing areas of the state. Other nematodes frequently found were species of Tylenchorbynchus, Pratylenchus, Helicotylencbus, Meloidogyne, and Criconemoides. No direct relationship was indicated between pear decline and nematodes in orchard soils.

III. Reduction of populations of pin nematodes, spiral nematodes, and stunt nematodes in orchard soil by fumigation with ethylene dibromide did not improve the growth of Bartlett or Oriental pear seedlings. The results suggest that these nematodes are not an important factor limiting growth of pears in California. 
The journal HILGARDIA is published at irregular intervals, in volumes of about 650 to 700 pages. The number of issues per volume varies.

Single copies of any issue may be obtained free, as long as the supply lasts; please request by volume and issue number from:

$$
\begin{aligned}
& \text { Agricultural Publications } \\
& \text { University Hall } \\
& \text { University of California } \\
& \text { Berkeley, California } 94720
\end{aligned}
$$

The limit to nonresidents of California is 10 separate titles. The limit to California residents is 20 separate titles.

The journal will be sent regularly to libraries, schools, or institutions in one of the following ways:

1. In exchange for similar published material on research.

2. As a gift to qualified repository libraries only.

3. On a subscription basis $-\$ 7.50$ a year paid in advance. All subseriptions will be started with the first number issued during a calendar year. Subscribers starting during any given year will be sent back numbers to the first of that year and will be billed for the ensuing year the following January. Make checks or money orders payable to The Regents of The University of California; send payment with order to Agricultural Publications at above address. 